\title{
Towards Need based Teacher Development Programme
}

\author{
Kothakota Parasurama* \\ Research Scholar, Dravidian University, Srinivasapuram, Kuppam, India \\ *Corresponding author: parasuramak21@ gmail.com
}

\begin{abstract}
English Language has been taught as a second language in a multilingual situation in India where a three language formula is in practice as language policy of the country. The other two languages are the regional language and Hindi the assumed national language. English language teaching begins at different levels in the different states of India. In states like Andhra Pradesh it begins from class1. To develop proficient users of this language has been the ultimate objective of teaching it at the school and collegiate levels. To develop the same, the need of the hour as it has been is the development of a cadre of facilitators of language learning whose abilities need to be of a high order and are equipped with a set of core and soft skills and with craft knowledge required for an effective transaction of the prescribed content and thus realize the desired curricular objectives. Besides, the teacher of English in the changing scenario has to be a willing co participant in the language learning process. In this background this paper attempts to identify those skills required of the practicing teacher and the need for having an alternative need based curriculum at the teacher training programme levels with special reference to in service teacher training programmes.
\end{abstract}

Keywords: ESL, Objectives, Teacher training and development.

\section{Introduction}

English has been taught as Second Language in India with the sole objective of developing what is known communicative competence of the learners at different levels. In other words, the objective of teaching this link language or the language of the internet in the present scenario is to develop in the learners the ability to be fluent, accurate and appropriate in both the productive or expressive and receptive or decoding skills namely speaking and writing and listening and reading respectively. The learners of English also need to be taught the nuances of the language in speech and writing and the need to be equipped with a set of skills and language elements so as to be appropriate to the contexts in which communication takes place. The contexts may however be formal or informal. In terms of skills, they need to be taught the strategies for acquiring them and learning them consciously. In a formal situation like the school the focus hither to has been the teaching of the four language skills namely listening, speaking, reading and writing. The system has been for a long time teacher centered based on the behaviourist stimulus response theory of learning for which the goal is only product or learning through conditioning to produce the desired response. The shift in the paradigm in the last four decades however has been on the processes of learning and thus learner centered.

An extension of this cognitive perspective is the focus on the learner managing on his or her own learning ways and processes by getting provided with a zone called zone of proximal development from where he or she takes off. Further he or she will be able to hold on to the scaffold provided in the classroom either by the teacher or the peers. He or she constructs language expressions to convey meaning. In other words, the learner acquires the language by getting situated in an acquisition rich environment. The shift in the theoretical perception is towards learning centeredness. The shifts differing however the focus is on the learner becoming proficient user of the target language and the curricular objective remaining the same with a different approach in line with the theoretical perception to the development of content for formal learning in other words the textbook design. The text book is designed to realize the objectives of teaching and learning the target language. The realization of the objective depends also on the effective transaction of the content in the classroom. The teacher's role thus becomes vital.

The trend in text book designing is based on the theory of constructivism which puts the emphasis more on learners becoming independent of the teacher and the teacher providing the right zone for development and those language inputs that trigger learning and process learning in the route to the understanding of the content and constructing and evolving new structures of language in order to express what has been comprehended and also to extend them for new knowledge acquisition through the use of language.

In the light of the shifts mentioned above the role of the teacher will then be that of an agent of learner empowerment by making language learning occur. The teacher can no more be the one who makes the transaction of the content unidirectional. He or she will have to be an agent of change and make learning and teaching interactive the interacting will be the learners, the teacher, the content prescribed and the environment in general for the environment may act as a trigger for learning and interaction to take place in which there will be enough opportunity for the learner to put to use the language already received and to acquire the new elements in terms of vocabulary and structures and then to put to test the acquiring elements . 
The teacher in the classroom is then expected to have a set of strategies that help not only the learner but the teacher himself or herself. There are many time tested strategies and yet there is no end to the teacher and becoming self-empowered and thus develop oneself. The teacher besides his teaching competence must possess that competence which includes his language competence, communication skills and effective classroom management skills and his readiness to reflect on his own classroom teaching and its impact. A developing teacher must be open minded and open to criticism and self-critique always questioning the cause for the failure in the use of one or the other teaching technique. He must be a reflective practitioner. In other words, he must have a sufficient amount of what is called craft knowledge which is rooted in the teacher's practical experience and is directly linked to his everyday practice. It describes the knowledge that arises from and in turn informs what teachers actually do in their class. This knowledge develops through the process of reflection. It also flows through problem solving which teachers get engaged with in carrying out the demands of their vocation. Craft knowledge is essentially the accumulated wisdom of teachers. It is action oriented knowledge which may not be explicitly made known. Craft knowledge can be acquired by getting exposed to different models of practice, by involving oneself in action research, classroom observation, using the plans of lessons as tools for reflection. Peer evaluation, classroom journals and self-dairies of everyday classroom events and schedules and learner feedback and self-evaluation reports besides other tools for promoting reflective teaching practice.

The need of the hour is then to look at the formal teacher development programmes. They need to be highly need based and skill focused and must have a lot of space for practice and discussion than input giving sessions. Input sessions also can be incorporating in them both practice and knowledge driven.

\section{Conclusion}

A need based teacher development programme needless to say will have focus on orientation to the trends but must have more focus on providing more opportunities for reflection. Such a need based programme will certainly help the teacher with more of professional craft knowledge required and thus help the teacher not only self-empowered but also accelerate the process of language learning in the classroom. Whatever may be the potentials of technology assisted learning there cannot be a substitute for a highly developed teacher in the class room. The one and only substitute is the teacher and none else. Thus the argument for need based teacher development programmes and thus become very effective agents of change, facilitating the realization of the objectives of teaching English as the second language in the Indian pluralistic society.

\section{References}

[1] Asher, J. Learning Another Language through Actions: The Complete Teacher's Guidebook. Los Gatos, CA: Sky Oak Productions (1977).

[2] Bhandari, C.S and others, Teaching English: A Handbook for Teachers (Orient Longmans, New Delhi, 1966).

[3] Billows FL. The Techniques of Language Teaching (Longmans, 1961).

[4] Bright, GA and Mc Greogor, GP Teaching English as a second Language (Longmans, 1982).

[5] Brown, G \& Yule, G, Teaching the Spoken Language, Cambridge, CUP (1985).

[6] Chaudron, C. Second Language Teaching analysis London: Longman. (1988)

[7] Harris, David P. Testing English as a Second Language, Tata Mc Graw Hill (1974)

[8] Lado Robert, Language Teaching, A Scientific Approach (Tata McGraw Hill New Delhi, 1964)

[9] Mackey, W F, Language Teaching Analysis (Longmans, 1965).

[10] NS Prabhu, Second Language Pedagogy (1987).

[11] Rivers, W. M. Teaching Foreign Language Skills. Chicago University Press (1968).

[12] Terrell, Tracy D Natural Approach to Language Teaching (1983).

[13] Widdowson HG Teaching Language as communication, (1978). 